\section{Alterations on flow variability due to converting hardwood forests to pine}

\author{
Yusuf Serengil ${ }^{(1)}$, Wayne T Swank ${ }^{(2)}$, James M Vose ${ }^{(2)}$
}

Flow variability is a potential indicator of land use impacts on aquatic ecosystems and a dominating factor for lotic habitats. Vegetation management effects on the stream habitat conditions must be better understood to propose forest management activities that are compatible with general ecosystem management objectives (integrity, diversity, sustainability, etc.). In our study, we used long term flow data (1936-2004) from four gauged experimental watersheds (W1, W2, W17, W18) of Coweeta Hydrologic Laboratory in US to assess the impacts of pine conversion on flow characteristics by using paired watershed experimentation. In W1, all trees and shrubs were cut and burned in 1956-57 and white pine (Pinus strobus) was planted in 1957. In W17, white pine was planted in 1956. W2 and W18 have been kept untreated as reference watersheds for $\mathrm{W} 1$ and $\mathrm{W} 17$, respectively. After analyzing long-term daily flow series with flow duration curves and frequency analyzes, we found that the timing and magnitude of $7 Q$ flows were changed significantly due to conversion but flow variability was not affected. Overall findings revealed that pine conversion has significantly influenced some flow characteristics but stream habitat conditions were not affected potentially.

Keywords: Flow variability, Conversion to pine, Ecological flows, High-low flow frequency

\section{Introduction}

Sustainable management of forest ecosystems involves application of adequate forestry treatments towards maintaining their biodiversity, productivity, regeneration capacity, vitality and their potential to fulfill relevant functions (McDonald \& Lane 2004). The adequacy of a forestry treatment depends on many parameters but sustainability of the ecosystem in consideration is always the key objective. Sustainability and health of lotic habitats in forestlands can be accepted as an important criterion for assessing the impacts of treatments. However, biologic investigations have always been complex and time consuming. Flow assessment tech-

(1) Dept. of Watershed Management, Istanbul University, Istanbul (Turkey); (2) Coweeta Hydrologic Laboratory, Southern Research Station, USDA Forest Service, 3160 Coweeta Lab Road, 28763 Otto, NC (USA).

@ Yusuf Serengil (serengil@istanbul.edu.tr)

Received: Oct 24, 2011 - Accepted: Feb 08, 2012

Citation: Serengil Y, Swank WT, Vose JM, 2012. Alterations on flow variability due to converting hardwood forests to pine. iForest 5: 44-49 [online 2012-04-30] URL: http:// www.sisef.it/iforest/contents/?id=ifor0609009

Communicated by: Roberto Tognetti niques on the other hand provide practical evaluation methods as long as the linkage between flow characteristics and biotic environment is known (Wood et al. 2000). Many flow assessment techniques can be used in this respect including the ones that address flow variability (Azzellino \& Vismara 2001, Huh et al. 2005).

Flow variability, a major aspect of hydrological behavior is a potential indicator of land use and a control on river ecology (Archer \& Newson 2002). It is also the dominating factor for lotic habitats according to stream ecologists (Resh et al. 1988). The effects of land use disturbances on flow variability have rarely been studied with respect to forestry activities. In particular, the effects of forestry on low flows are not widely understood due to the various conflicting evidence available from limited number of reported studies (Johnson 1998, Smakhtin 2001).

It is obvious that any disturbance that causes changes on sediment loads, water quality, and flow regime also has the potential to affect overall in-stream habitat quality. There are two main points that should be addressed: (1) the methodology required to identify flow variability; and (2) identification of forestry treatments that affect or control flow variability. Approaches that focus on benthic macroinvertebrates as monitors of stream health and thus incorporate hydraulic habitat conditions as part of bioassessment are widely accepted in recent decades (i.e.,
Gore et al. 2001). This statement has been supported by many authors (i.e., Richter et al. 1996, Wood et al. 2000, Azzellino \& Vismara 2001, Wood \& Armitage 2004). Furthermore, Clausen \& Biggs (1997) showed that measures of flow variability, amongst all tested flow parameters, had the most significant correlations with biological variables including species richness and diversity.

A number of recent studies have proposed hydrological parameters that are indicative of stream ecological conditions. The IHA (Indicators of Hydrologic Alteration) method developed by Richter et al. (1996, 1997) uses 32 parameters organized in five groups that include minimum maximum flows, and other common hydrologic parameters. In another study, invertebrate community data were analyzed using a correspondence analysis by Wood et al. (2000) to find the most relevant hydrological parameters. The best hydrological indicators were the monthly mean, maximum and minimum flows, mean daily discharge at a lag of 7 days, and dry weather flow index (DWF). The flows recorded over longer periods of time (3, 6 and 12 months) were ecologically poor indicators. Wood \& Armitage (2004) supported these results with another study that suggests D-7 (mean daily discharge measured 7 days prior to sampling), M-7 (mean daily discharge for 7 months prior to sampling) and DWF (average of the seven consecutive days of lowest discharge in the 12 months prior to sampling) to be the best indicators of ecological condition. These studies, linking stream fauna dynamics with flow parameters, provided a very useful tool for assess forestry treatments.

Forestry treatments have rarely been subject to stream habitat condition assessments though many of them (cutting, conversion, prescribed burning, etc.) are expected to alter hydrological conditions in a watershed. Furthermore, impacts of forestry activities on stream habitat conditions, riparian ecosystems and extreme flows has been recently identified as a research gap (Serengil et al. 2011a).

Among the forestry treatments, species conversion has been an important forest practice for centuries. In Europe, conversion to pine started in the late $18^{\text {th }}$ century for the restoration of degraded broad leaved forests (Spiecker 2003, Ammer et al. 2006). As the result of widespread conversions, today, coniferous forests expand far beyond the limits of their natural habitats (Spiecker 2003). In many European countries conversion back to broadleaved stands, particularly in problematic areas (e.g., acidity), is now being strongly recommended and encouraged (Ammer et al. 2006). Species conversion has been a common practice in the history of North American forests (Hessburg \& 
Fig. 1 - Experimental watersheds of Coweeta Hydrologic Laboratory (Serengil et al. 2011b)

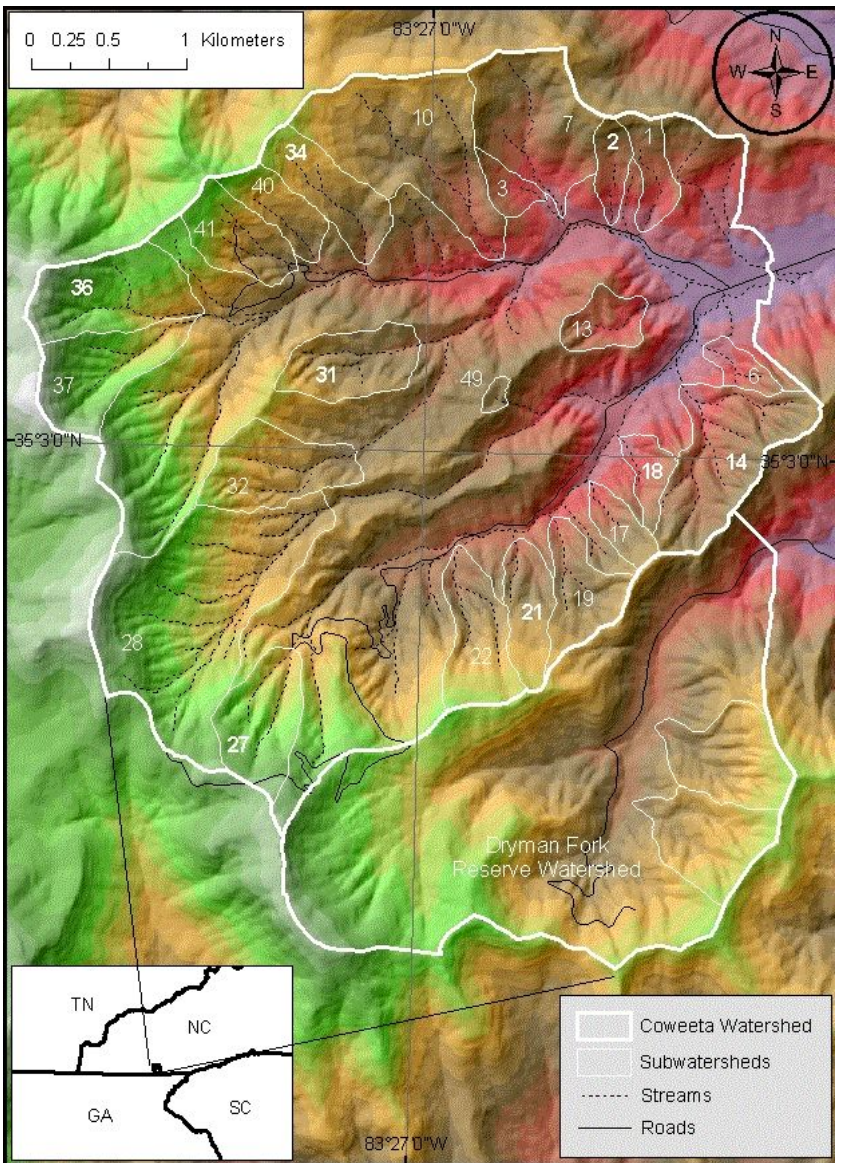

Agee 2003) for achieving a more economical product (including agro-forestry practices, and fast growing species), restoration and rehabilitation, or for various other objectives.

In any case, a change in the species composition can potentially alter ecological conditions. A substantial amount of research has been conducted to understand the effects of changing species composition from many aspects. Most of the efforts to identify the hydrological consequences have focused on water yield (Erol 2011), quality or extreme events. The hydrological consequences of species conversion treatments, mostly from

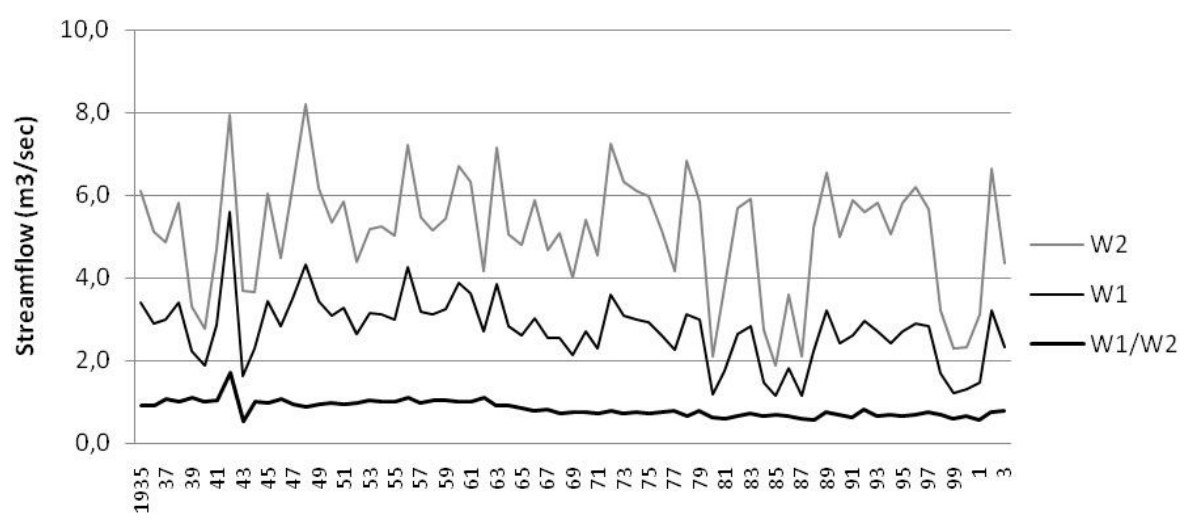

Years

Fig. 2 - Annual mean flows and flow ratios of watersheds 1 and 2 for the whole evaluation period.
1997).

The influence of species conversion on extreme flows was investigated with the emphasis on timing and magnitude (Serengil et al. 2011b). The annual maximum and minimum flows were found to be affected from conversion some ten years following the treatment. This study was initiated based on the hypothesis that ecological flow responses to species conversion and flow variations can be different than annual maximum and minimum flow responses. It is a follow up of Serengil et al. (2011b) that focus on ecologically significant flows and flow variability. More specifically our objective here is to evaluate flow characteristics related to stream habitat conditions. The ecologic flow characteristics are linked with dimensions, variations and durations. It is a well known fact that biotic populations are affected from ecologic flows like long duration high-low flows (i.e., 7Q10) than single high-low events (i.e., annual maximum flow). Certain ecologic flow indexes can be analyzed for forestry treatments and their potential influences on stream habitat conditions can be discussed.

In this study the influences of conversion for its potential to change the in-stream habitat conditions by using streamflow variability evaluation techniques.

\section{Material and methods}

water yield and flow regime aspects were evaluated to some extent (i.e., Swank et al. 1988, Brown et al. 2005). A limited number of studies sought the effects of these treatments on the in-stream biotic components of an ecosystem and the common methodology was using the fauna population dynamics (i.e., Wallace et al. 1996, Stone \& Wallace 1998, Woodcock et al. 2003). It is now widely accepted that natural characteristics (duration, frequency and rate of change) of hydrological regimes, are critical in sustaining native biodiversity and integrity of aquatic ecosystems (Richter et al. 1996,

\section{Experimental watersheds}

The Coweeta Hydrologic Laboratory is located in the Nantahala Mountain Range of western North Carolina, latitude $35^{\circ} 03^{\prime} \mathrm{N}$, longitude $83^{\circ} 25^{\prime}$ W (Fig. 1). Thirty-two streams draining experimental watersheds have been instrumented and studied since the establishment of Coweeta in 1934. Currently 16 weirs are in operation (Swank \& Crossley 1988). Climate is classified as Marine, Humid Temperate and characterized by mild winters and cool summers with abundant and uniform precipitation in all seasons. Average annual precipitation varies from $1700 \mathrm{~mm}$ at lowest point $(680 \mathrm{~m})$ to 2500 $\mathrm{mm}$ on upper elevations $(>1400 \mathrm{~m})$. The underlying bedrock consists of quartz diorite gneiss, metasandstone and peltic schist, and quartzose metasandstone. Soils are deeply weathered and average about $7 \mathrm{~m}$ in depth (Swank et al. 2001).

\section{Data sets}

Flow series were analyzed as ratios of treatment watersheds (W1, W17) to control watersheds (W2, W18) to remove the influence of climatic variations. This is the advantage of paired watershed approach. The mean flow data has been given as an example to this (Fig. 2). Annual instantaneous maximum, minimum, daily mean and 7 day consecutive flow series between 1934 and 
2004 were used in trend analysis and quantile estimation, and daily flow data was used for constructing flow duration curves (FDC) to extract annual Q10, Q50 and Q90 values.

\section{Field methods}

Long term flow data belonging to 4 experimental watersheds (W1, W2, W17, W18 Tab. 1) of Coweeta Hydrologic Laboratory are used in the analysis procedure. Watersheds 1 and 2 were instrumented with V-notch weirs in 1934 and W17 and W18 were instrumented with V-notch weirs in 1936. All trees and shrubs in W1 were cut and burned in 1956-57, no products were removed; and white pine (Pinus strobus) was planted in 1957. In subsequent years, pine was released from hardwood competition by cutting and chemicals as necessary. All woody vegetation of W17 was cut in 1940 and regrowth was cut annually thereafter in most years until 1955; no products were removed. White pine was planted in 1956. W2 and W18 are untreated and serve as reference watersheds for $\mathrm{W} 1$ and $\mathrm{W} 17$, respectively (Swank \& Crossley 1988).

\section{Methods of flow variability}

\section{Timing}

The effects of species conversion on interannual timing of $7 \mathrm{Q}$ flows was investigated using Mann Whitney-Pettitt test, a time series shift detection method (Kiely 1999, Serengil et al. 2011b). The results were compared with the change points of absolute minimum, maximum and mean values. In addition to this, the Julian dates of 7Q minimum and $7 \mathrm{Q}$ maximum values were calculated for both treatment and control watersheds and treatment/control ratios were calculated to be compared. This procedure required a more sensitive evaluation and undisturbed time series. Therefore, the time series were divided into 3 groups. Data from 1937-54 represented the pre-treatment period, The post-treatment period was divided into 2 time series to better understand the effects due to aging of the pine stands. The first series was 1970-1986 and the second was 1987-2003. Years between 1955-1957 (the time period of site preparation and planting) were excluded from the analysis to eliminate the effects of cutting. The effects due to cutting were not need to be taken into account as the treatment under investigation was the conversion to pine from deciduous forest.

\section{Magnitude}

We focused on the effects of conversion on low flows and assessed changes in flow dimensions of various recurrence intervals as a first step. Seven day consecutive flow rates at 2, 5, 10, 20, 50, and 100 years recurrences
Tab. 1 - Some properties of experimental watersheds (Swank \& Crossley 1988).

\begin{tabular}{clcccc}
\hline $\begin{array}{c}\text { Watershed } \\
\text { Number }\end{array}$ & $\begin{array}{c}\text { Name of } \\
\text { Stream }\end{array}$ & $\begin{array}{c}\text { Area } \\
\text { (ha) }\end{array}$ & $\begin{array}{c}\text { Elevation at } \\
\text { Weir }(\mathbf{m})\end{array}$ & $\begin{array}{c}\text { Maximum } \\
\text { elevation (m) }\end{array}$ & Aspect \\
\hline 1 & Copper Branch & 16 & 705 & 988 & S \\
2 & Shope Branch & 12 & 709 & 1004 & SSE \\
17 & Hertzler Branch & 13 & 760 & 1021 & NW \\
18 & Grady Branch & 13 & 726 & 993 & NW \\
\hline
\end{tabular}

were calculated with traditional quantile estimation procedure for the period before treatment (1934-1956) and post treatment (1957-2004) periods.

7Q low flow duration curves (L-FDC) were prepared for all 4 watersheds to assess whether conversion affected low flows throughout the period in consideration. FDCs represent all flow values in a time interval in this case all 7Q low flows before the low flows changed due to conversion, and after. They can be prepared for various intervals and flow types. Percentage of years $7 \mathrm{Q}$ low flow values exceeded are plotted on the graph to see if there is a shift at $7 \mathrm{Q}$ low flows in general.

\section{Low and high flow variability}

The flow variability in this section covers the time series analysis of ratios of high and low flow values to mean flows. Q90/50 and Q10/50 values for treatment watersheds were extracted from data series and standardized by dividing into control watershed values. Q50 represents the median flow, Q90 and Q10 are the flow values that 90 and 10 percent of the flows are above them. Therefore, Q90 is a low flow value, Q10 is a high flow value. The Q90/50 represents low flow variability, Q10/50 represents high flow variability.

\section{Results and discussions}

The flow series of control and treatment watersheds indicated significant variations throughout the monitoring period. The reason of the variations could be caused by short term (cutting, fires etc.) and long term (species conversion, regrowth etc.) disturbances mentioned above. Long and short term changes in climatic variables are also visible on the time series given in Fig. 2 above. There have been high flow (1989-96)

and low (1985-87) flow periods. Changes in precipitation patterns in the region have already been reported by Serengil et al. (2011b). As seen on the figure new time series of ratios is free from the influences of natural variations.

\section{Timing}

An important aspect of streamflow response to disturbance is the timing of response. Mann Whitney-Pettitt test revealed that the major long term variations on streamflow of treatment watersheds were caused by conversion to pine. The streamflows of these watersheds responded to the conversion with decreasing annual mean flows (AMR) starting in 1968. This means that an 11 years delay occurs for annual streamflows to respond to the conversion. Annual maximum (AXR), annual minimum (ANR), 7QMinimum and 7QMaximum flow ratio series were changed at different but close durations after conversion (Tab. 2).

More specifically, annual mean flows started to decrease in 1968 in both watersheds (W1 and W17); however, the maximum annual flows were affected less and the change point for AXR was 1976 for W1 and 1972 for W17. The annual minimum flows were also affected strongly, but change points were similar for both watersheds (e.g., 1965 for W1 and 1966 for W17). On the other hand, 7 day minimum flows changed at the same year for W1, but change point for W17 was 1968 , two years after the change point of annual minimum flows. Seven day maximum flows were more strongly (higher significance level) and quickly affected from conversion compared to annual maximum flows. The change point for 7QMax flows were 1968 for W1 and 1969 for W17 closer to AMR compared to AXR suggesting that long duration flows are more reliable than

Tab. 2 - Primary change point (CP) years, direction of change (D: Decrease; I: Increase), and the significance of shift for all time series. Less significant CPs are also given as secondary.

\begin{tabular}{lcccc}
\hline \multirow{2}{*}{ Time series } & \multicolumn{2}{c}{ W1/W2 } & \multicolumn{2}{c}{ W17/W18 } \\
\cline { 2 - 5 } & Primary & Secondary & Primary & Secondary \\
\hline AMR & $1968-D-0.99$ & $1980-D-0.98$ & $1968-D-0.99$ & $1980-D-0.98$ \\
AXR & $1976-D-0.98$ & n/a & $1972-D-0.99$ & n/a \\
ANR & $1965-D-0.99$ & $1978-D-0.81$ & $1966-D-0.99$ & $1995-\mathrm{I}-0.98$ \\
7QMin & $1965-D-0.99$ & $1977-D-0.90$ & $1968-D-0.99$ & n/a \\
7QMax & $1968-D-0.99$ & n/a & $1969-D-0.99$ & n/a \\
\hline
\end{tabular}


Tab. 3 - Timing of 7Q minimum and maximum flows. (CV): coefficient of variation.

\begin{tabular}{llrrrrrc}
\hline \multirow{2}{*}{ Dates } & \multirow{2}{*}{ Series } & \multicolumn{3}{c}{ Mean } & \multicolumn{3}{c}{ CV } \\
\cline { 3 - 7 } & & $\mathbf{1 9 3 7 - 5 4}$ & $\mathbf{1 9 7 0 - 8 6}$ & $\mathbf{1 9 8 7 - 0 3}$ & $\mathbf{1 9 3 7 - 5 4}$ & $\mathbf{1 9 7 0 - 8 6}$ & $\mathbf{1 9 8 7 - 0 3}$ \\
\hline Julian date of & W1 & 266.17 & 282.06 & 232.18 & 0.36 & 0.26 & 0.45 \\
7QMin flow & W2 & 244.89 & 269.82 & 234.18 & 0.37 & 0.08 & 0.36 \\
& W17 & 269.28 & 290.65 & 235.41 & 0.3 & 0.11 & 0.47 \\
& W18 & 280.17 & 282.65 & 228.24 & 0.26 & 0.1 & 0.46 \\
& W1/W2 & 1.09 & 1.05 & 0.99 & 0.97 & 3.07 & 1.23 \\
Julian date of & W17/W18 & 0.96 & 1.03 & 1.03 & 1.13 & 1.17 & 1.03 \\
7QMax flow & 110.72 & 82.76 & 113.35 & 0.96 & 0.92 & 0.94 \\
& W2 & 113.17 & 76.24 & 112.53 & 0.93 & 0.59 & 0.87 \\
& W17 & 131.33 & 79.65 & 107.53 & 1.03 & 0.94 & 0.92 \\
& W18 & 91.78 & 88.35 & 107.65 & 1.14 & 0.87 & 0.78 \\
& W1/W2 & 0.98 & 1.09 & 1.01 & 1.03 & 1.56 & 1.08 \\
& W17/W18 & 1.43 & 0.9 & 1 & 0.9 & 1.08 & 1.18 \\
\hline
\end{tabular}

Fig. 3 - The change in the recurrence of

7 day minimum

flows. The recurrence intervals are 2 ,

$5,10,20,50$, and

100 years represen-

ted by shrinking

circles respectively.

The largest circle represents 2 years return period, the smallest one 100 years.

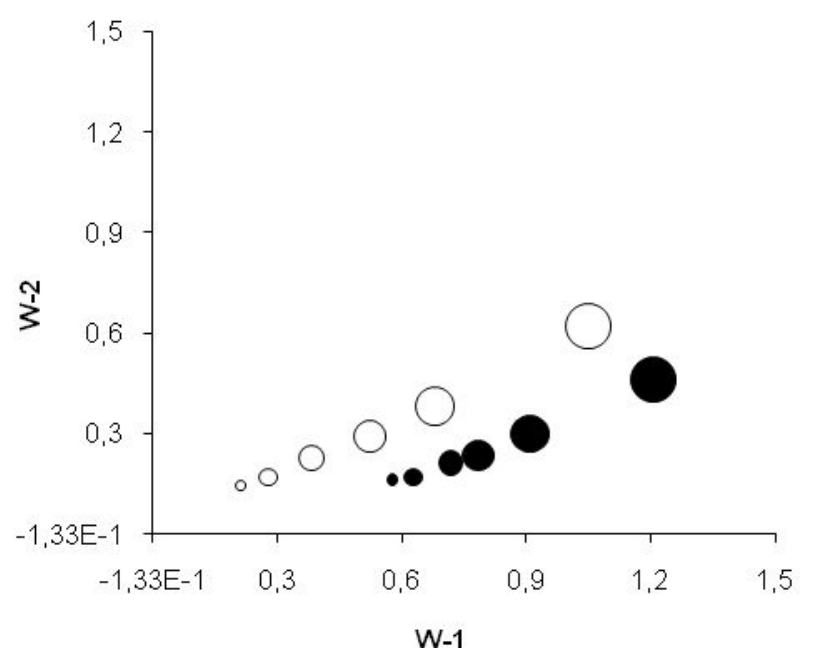

instantaneous flows to evaluate the impacts of disturbances like species conversion. The 7 Qmin flows changed at very close years with annual minimum flows but 7Qmax lows were affected earlier compared to AXR.

Flow of a stream generally follows a regular pattern throughout the year with respect to rising and falling limbs of interannual hydrographs. The rising limb follows the rainy period and peaks at some point. The lowest point of the hydrograph generally corresponds to the end of a low or no precipitation period. The lowest and highest points may shift for or back according to the precipitation characteristics of the year affecting the life cycles of steam biota. The paired watershed approach provided us to evaluate the changes in timing of 7Qlow and high flows due to conversion to pine. The time series was divided into 3 periods to evaluate the interannual timing of 7 days minimum and maximum flows as explained in methods. The timing ratios of $\mathrm{W} 1 / \mathrm{W} 2$ for $7 \mathrm{Qmin}$ flows were $1.09,1.05$, and 0.99 , pointing out a date pulled forward due to conversion to pine (Tab. 3). However, W17/W18 resulted
W-1

\section{W1-W2 Q7MA}

$\bullet$ BT

OAT in a delayed date.

The 7 day maximum flow of $\mathrm{W} 1$ was $110.72^{\text {th }}$ day before the treatment, which corresponds to the second half of April. It moved forward to second half of March $\left(82.76^{\text {th }}\right.$ day) in the first period $(1970-86)$ after conversion and then delayed to second half of April again (113.35 $5^{\text {th }}$ day). When these values were divided to the control watershed values then the picture was opposite; a delayed timing for the first period compared to before treatment (from 0.98 to 1.09) and a very similar timing for the second period (1987-03) compared to again before treatment conditions. For the case of W17; 1.43 before pretreatment ratio dropped to 0.90 in the first period which is a very sharp change, but again raised to 1.00 at the second period. The reasons we discussed above for the low flows were also valid for 7 day maximum flows.

\section{Frequency-Magnitude}

The conversion to pine resulted in changes in recurrence of 7 days minimum and maximum flows and also flow regimes. The ef- fects the conversion was very clear on mean flows (Swank et al. 1988) and minimum flows (Fig. 3). The 7 day minimum flows for various recurrences decreased for all intervals on both treatment watersheds. In W1, 7 day minimum flows decreased for all return periods while event sizes increased for W2 except 50 and 100 years return periods. The W2 event size for 50 and 100 years were almost the same for pre- and post-treatment periods.

\section{Conclusions}

Streamflow affects the habitat quality of lotic populations. Furthermore, streamflow variability is a significant factor governing the distribution of stream flora and fauna. The importance of low and high flows in aquatic ecosystems is well established but the effects of forestry treatments on ecologic streamflow indices have not been well documented.

Seasonal and between-year variations in flow regime of streams are normal and the stream communities are generally able to withstand the variations. However, human impacts for management purposes may alter the ecosystem and its responses substantially.

In this study we dealt with timing, frequency, magnitude, and variability aspects of flow characteristics to evaluate the changes due to species conversion treatment at experimental watersheds. Paired watershed approach provided very precise results of changes in streamflow and helped to eliminate the influence of climatic variability. We could assess the change in flow responses due to conversion to pine with this well established method and long term flow data.

Many attributes of the watersheds may alter response of streamflow to a disturbance. In our study, W1 (south facing) and W17 (north facing) had similar responses to conversion to pine with respect to timing, magnitude and low/high flow variability. The only visible difference was about interannual changes in the timing of ecological low and high flows which suggests that species conversion is not the major factor and facing of the watersheds might be affecting the results. In other words, the changes in Julian date of ecologic maximum and minimum flows in time series could not be explained with the conversion to pine. The precipitation pattern should be evaluated with a more concentrated approach to discuss this issue.

The responses of treatment watersheds to conversion corresponded to similar years in case of $7 \mathrm{Q}$ maximum and minimum flows. The timing response of this ecologic flow indice was closer to annual mean flow values compared to annual maximum or minimum flow values especially in cases of maximum flows. The 7 day maximum and minimum flows were also affected from conversion for 


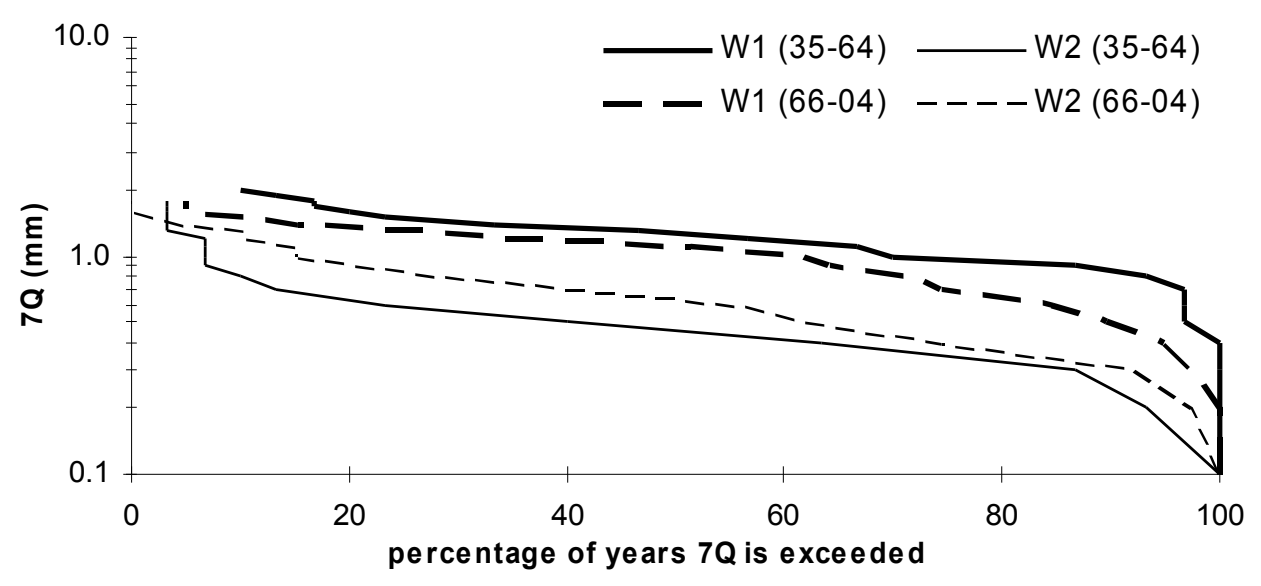

Fig. 4 - Low flow duration curves of the experimental watersheds.
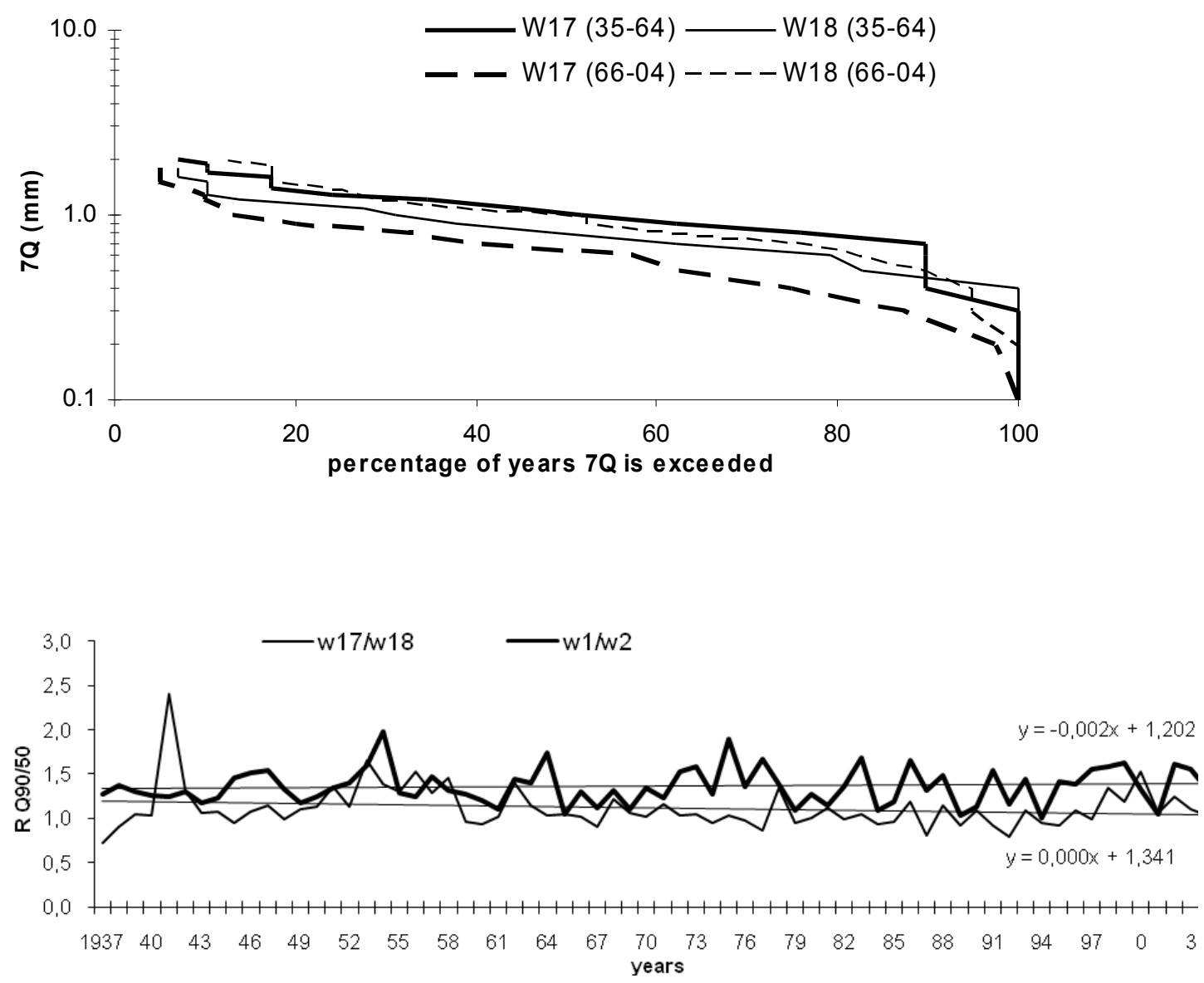

Fig. 5 - Time series of Q90/50 flow series.

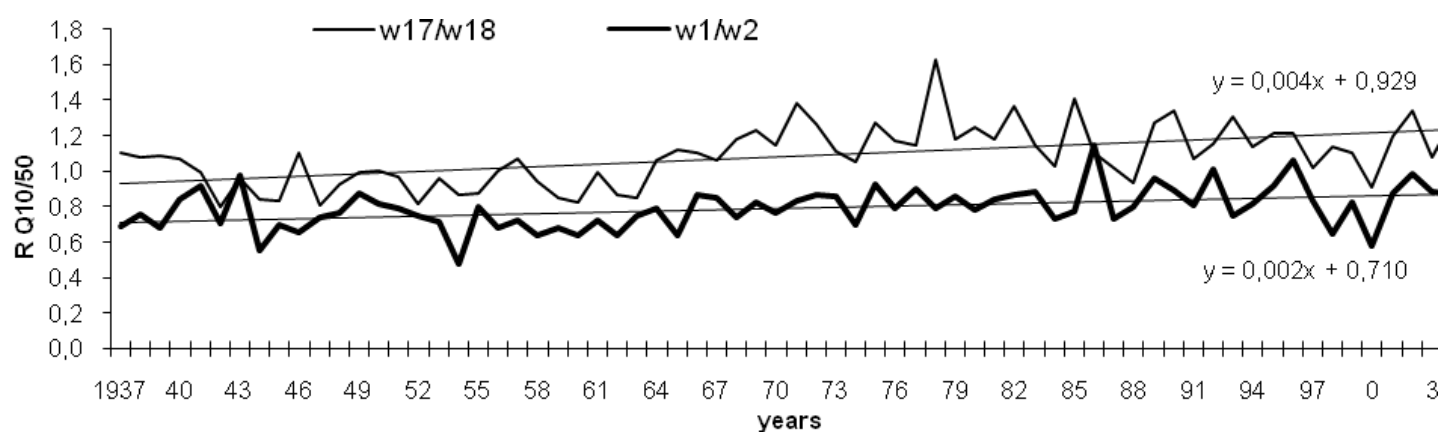

Fig. 6 - Time series of Q10/50 flow series. 
magnitude and frequency.

The low flow variability (Fig. 4) indice of RQ90/50 has not changed significantly throughout the time series but high flow (Fig. 5) indice RQ10/50 had a rising trendline (Fig. 6). Low flow variability has not been affected from conversion to pine according to this result. It has also not affected from any cutting treatment that have taken place. The high flow variability increased over time with the increasing high flows. It can be concluded that conversion to pine affected the 7Q event sizes parallel with absolute minimum and maximum flows but has not affected flow variability or interannual occurrence of minimum and maximum flows.

Based on these results we conclude that ecologic flow parameters including the timing and magnitude of 7Q high and low flows have been affected significantly but flow variability has not been changed due to conversion to pine.

\section{References}

Ammer S, Weber K, Abs C, Ammer C, Prietzel J (2006). Factors influencing the distribution and abundance of earthworm communities in pure and converted Scots pine stands. Applied Soil Ecology 33: 10-21. - doi: 10.1016/j.apsoil.2005. 09.005

Archer D, Newson M (2002). The use of indices of flow variability in assessing the hydrological and instream habitat impacts of upland afforestation and drainage. Journal of Hydrology 268: 244-258. - doi: 10.1016/S0022-1694(02)001713

Azzellino A, Vismara R (2001). Pool quality index: new method to define minimum flow requirements of high-gradient, low order streams. Journal of Environmental Engeneering 127: 1003-1013. - doi: 10.1061/(ASCE)0733-9372 (2001)127:11(1003)

Brown LR, Gray RH, Hughes RM, Meador MR (2005). Introduction to effects of urbanization on stream ecosystems. American Fisheries Society Symposium 47: 1-8. [online] URL: http://water.usgs.gov/nawqa/urban/pdf/Brown_IntroUrbanEffects.pdf

Clausen B, Biggs BJF (1997). Relationships between benthic biota and hydrological indices in New Zealand streams. Freshwater Biology 38: 327-342. - doi: 10.1046/j.1365-2427.1997. 00230.x

Erol A (2011). Impact of land use on water yield in Darideresi watershed, Turkey. African Journal of Agricultural Research 6 (20): 4699-4704. [online] URL: http://www.academicjournals.org/ AJAR/PDF/pdf2011/26\%20Sept/Erol.pdf

Gore JA, Layzer JB, Med J (2001). Macroinvertebrate instream flow studies after 20 years: a role in stream and river restoration. Regulated Rivers 17: 527-542. - doi: 10.1002/rrr.650

Hessburg PF, Agee JK (2003). An environmental narrative of Inland northwest US forests, 18002000. Forest Ecology and Management 178: 2359. - doi: 10.1016/S0378-1127(03)00052-5

Huh S, Dickey, DA, Meador MR, Ruhl KE (2005). Temporal analysis of the frequency and duration of low and high streamflow: years of record needed to characterize streamflow variability. Journal of Hydrology 310: 78-94. - doi: 10.1016/j.jhydrol.2004.12.008

Johnson R (1998). The forest cycle and low flow river flows: a review of UK and international studies. Forest Ecology and Management 109: 17 - doi: 10.1016/S0378-1127(98)00231-X

Kiely G (1999). Climate change in Ireland from precipitation and streamflow observations. Advances in Water Resources 23 (2): 141-151. doi: 10.1016/S0309-1708(99)00018-4

Mcdonald G, Lane M (2004). Converging global indicators for sustainable forest management. Forest Policy and Economics 6 (1): 63-70. - doi: 10.1016/S1389-9341(02)00101-6

Resh VH, Brown AV, Covich AP, Gurtz ME, Li HW, Minshall GW, Reice SR, Sheldon AL, Wallace JB, Wissmar RC (1988). The role of disturbance in stream ecology. Journal of the North American Benthological Society 7 (4): 433. doi: $10.2307 / 1467300$

Richter BD, Baumgartner JV, Powell J, Braun DP (1996). A method for assessing hydrologic alteration within ecosystems. Conservation Biology 10 (4): 1163-1174. - doi: 10.1046/j.1523-1739. 1996.10041163.x

Richter B, Baumgartner J, Wigington R, Braun D (1997). How much water does a river need? Freshwater Biology 37 (1): 231-249. - doi: 10.1046/j.1365-2427.1997.00153.x

Serengil Y, Augustaitis A, Bytnerowicz A, Grulke N, Kozovitz AR, Matyssek R, Müller-Starck G, Schaub M, Wieser G, Coskun AA, Paoletti E (2011a). Adaptation of forest ecosystems to air pollution and climate change: a global assessment on research priorities. iForest 4: 44-48. doi: 10.3832/ifor0566-004

Serengil Y, Swank WT, Riedel MS, Vose JM (2011b). Conversion to pine: changes in timing and magnitude of high and low flows. Scan- dinavian Journal of Forest Research 26 (6): 568575. - doi: 10.1080/02827581.2011.608710

Smakhtin V (2001). Low flow hydrology: a review. Journal of Hydrology 240 (3-4): 147-186. doi: 10.1016/S0022-1694(00)00340-1

Spiecker H (2003). Silvicultural management in maintaining biodiversity and resistance of forests in Europe-temperate zone. Journal of Environmental Management 67 (1): 55-65. - doi: 10.1016/S0301-4797(02)00188-3

Stone MK, Wallace JB (1998). Long-term recovery of a mountain stream from clear-cut logging: the effects of forest succession on benthic invertebrate community structure. Freshwater Biology 39 (1): 151-169. - doi: 10.1046/j.13652427.1998.00272.x

Swank WT, Swift LW, Douglass JE (1988). Streamflow changes associated with forest cutting, species conversions, and natural disturbances. In: "Forest hydrology and ecology at Coweeta" (Swank WT, Crossley Jr DA eds). Ecological Studies, vol. 66, Springer, New York, USA, pp. 297-312.

Swank WT, Crossley DA (1988). Forest hydrology and ecology at Coweeta. Ecological Studies, vol 66, Springer-Verlag, New York, USA.

Swank W, Vose J, Elliott K (2001). Long-term hydrologic and water quality responses following commercial clearcutting of mixed hardwoods on a southern Appalachian catchment. Forest Ecology and Management 143 (1-3): 163-178. - doi: 10.1016/S0378-1127(00)00515-6

Wallace JB, Grubaugh JW, Whiles MW (1996). Biotic indices and stream ecosystem processes: Results from an experimental. Ecological Applications 6 (1): 140-151. - doi: 10.2307/226 9560

Wood PJ, Agnew MD, Petts GE (2000). Flow variations and macroinvertebrate community responses in a small groundwater-dominated stream in south-east England. Hydrological Process 14: 3133-3147. - doi: 10.1002/1099-1085 (200011/12)14:16/17<3133::AID-HYP138>3.0. CO;2-J

Wood P, Armitage P (2004). The response of the macroinvertebrate community to low-flow variability and supra-seasonal drought within a groundwater dominated stream. Archiv für Hydrobiologie 161 (1): 1-20. - doi: 10.1127/00039136/2004/0161-0001

Woodcock RW, McGrew KS, Mather N, Schrank FA (2003). Woodcock-Johnson III diagnostic supplement to the tests of cognitive abilities. Itasca, Riverside, IL, USA. 